President-Charles E. Bessey, University of Nebraska, Lincoln, Nebraska.

Vice-presidents.-A, Mathematics and Astronomy, Edwin B. Frost, Yerkes Observatory, Williams Bay, Wisconsin; B, Physics, Robert A. Millikan, University of Chicago, Chicago, Illinois; C, Chemistry, Frank K. Cameron, U.S. Department of Agriculture, Washington, D.C.; D, Mechanical Science and Engineering, Charles S. Howe, Case School of Applied Science, Cleveland, Ohio; E, Geology and Geography, Bohumil Shimek, State University of Iowa, Iowa City, lowa; F, Zoology, Henry F. Nachtrieb, University of Minnesota, Minneapolis, Minnesota; G, Botany, Frederick C. Newcombe, University of Michigan, Ann Arbor, Michigan; H, Anthropology and Psychology, George T. Ladd, Yale University, New Haven, Conn.; I, Social and Economic Science (vacant); $\mathrm{K}$, Physiology and Experimental Science, William T. Porter, Harvard Medical School, Boston, Mass.; L, Education, Edward L. Thorndike, Columbia University, New York, N.Y.

Permanent Secretary.-L. O. Howard, Smithsonian Institution, Washington, D.C.

General Secretary.-John Zeleny, University of Minnesota, Minneapolis, Minnesota.

Secretary of the Council.-Theodore S. Palmer, U.S. Department of Agriculture, Washington, D.C.

Secretaries of the Sections.-A, Mathematics and Astro nomy, George A. Miller, University of Illinois, Urbana, Illinois; B, Physics, Alfred D. Cole, Ohio State University, Columbus, Ohio; $\mathrm{C}$, Chemistry, Charles $\mathrm{H}$. Herty, University of North Carolina, Chapel Hill, N.C. D, Mechanical Science and Engineering, George W. Bissell, Michigan Agricultural College, East Lansing, Mich.; E, Geology and Geography, F. P. Gulliver, Norwich, Conn.; F, Zoology, Maurice A. Bigelow, Columbia University, New York, N.Y.; G, Botany, Henry C. Cowles, University of Chicago, Chicago, Illinois; $\mathrm{H}$, Anthropology and Psychology, George Grant MacCurdy, Yale University Museum, New Haven, Conn.; I, Social and Economic Science, Fred C. Croxton, I229 Girard Street, Washington, D.C.; K, Physiology and Experimental Medicine, George T. Kemp, 8 West 25th Street, Baltimore, Maryland; L, Education, Charles Riborg Mann, University of Chicago, Chicago, Illinois.

Treasurer.-R. S. Woodward, Carnegie Institution, Washington, D.C.

\section{SCIENCE AND POTTERY.'}

THE English Ceramic Society, founded about 1 ten years ago, had its origin in a belated attempt, made by a few enlightened manufacturers, to introduce scientific method into the conduct of one of our most important industries. There is a proverbial connection between the potter and his thumb, and in no other leading manufacture in this country is the rule of thumb so dominant or so repressive as it is in that of pottery. The ceramic art as practised in England is for the most part empirical, and is therefore highly conservative; changes are few and progress is correspondingly slow. At the same time, in certain respects, the industry has reached a high degree of mechanical perfection. English china is a product sui generis, and its merits are widely recognised, even by those who decline to regard it as a variety of porcelain. In the manufacture of the highest qualities of earthenware no nation has hitherto surpassed us. But signs are not wanting that our supremacy is challenged, and each succeeding decade sees the struggle becoming more and more acute. The industry is, in fact, between the upper and the nether millstones of conflicting tariff systems. Industrial conditions in the Potteries are, in some respects, without parallel in any other manufacturing district. In

1 Transactions of the English Ceramic Society. Vol. ix. Session rgog-ro (Stoke-on-Trent. Staffordshire : Published by the Society; Longton : Hughs and Harher, Ltd., igro.)

No. 2 I 52 , VOL. 85 ] no other staple trade of like magnitude is to be found so numerous a class of small manufacturers-persons of little or no capital and employing few hands-some of them no more than the members of their own families. These are for the most part ignorant of anything beyond the ordinary technique of their art. Even in the case of larger concerns, it was, until of late years, rare to meet with any evidence of practical recognition of the scientific principles underlying the industry. Such a condition of things cannot possibly tend to development in the art itself, or to improvement in the welfare of the workers engaged in it.

Ceramics is a branch of applied chemistry and physics, of chemical engineering in its most comprehensive sense. That this fact is beginning to be slowly appreciated may, we think, be inferred from the gradual increase in the number of the members of the English Ceramic Society. The society started in I900-I with 29 members; in 1909-10 its numbers were $26 \mathrm{I}$, but of these, it ought to be said, a certain fraction are engaged in American and Continental factories. But, after all, this growth in numerical strength is hardly commensurate with the value and importance of the society's objects, or with the influence it may be expected to exercise upon the development of the industry with which it is concerned. In the United Kingdom there are some $55^{\circ}$ potteries; of these 329 are concentrated in the group of towns known as the North Staffordshire Potteries. It is not unreasonable to expect that in the case of an institution centrally situated and in close proximity to Burslem, Fenton, Hanley, Longton, and Tunstall there would, after ten years of existence, be a membership equal at least to the number of factories in the neighbourhood. That such is not the case is only one more instance of the supineness and indifference of our manufacturers, as a class, to the bearing of physical science, its methods and its teaching, upon their industries.

Of the general character of the twenty-two contributions to the scientific work of the society contained in this volume we have nothing but commendation to offer. They all bear directly on problems of practical interest to the potter. The papers of $\mathrm{Mr}$. Fowler on the control of kiln and oven gases; of Messrs. Cobb and King on the fluxing power of the common oxides; the papers by Dr. Mellor on cylinder grinding, vitrification of clays, surface factors, softening temperatures of lead silica glazes, and the two excellent papers by Mr. Thomason, on the toxic possibilities of fritted lead glazes and on white lead and plumbism are of permanent value as additions to ceramic literature. The latter papers are of special interest at the moment in relation to the question of lead-poisoning in pottery manufacture. Mr. Thomason points out that the official returns from such factories as are working under the 5 per cent. standard of solubility, as defined by the method prescribed by $\mathrm{Sir}$ Edward Thorpe, and adopted in the Home Office special rules, show no cases of plumbism amongst workers in the prepared glazes, and that the information available from the Continent is to a similar effect. It has been objected to this method that it bears no real analogy to what actually goes on in the human system. Mr. Thomason effectually meets this objection. After a careful experimental inquiry of which full details are given in the papers, and in which, so far as possible, all the conditions known to occur in the animal body were separately and collectively studied, Mr. Thomason concludes that the solubility of a glaze in the stomach is properly gauged by the official method, and that the figures so obtained are fair statements of its toxic possibilities.

These papers were evidently not verv pleasant hear- 
ing to at least one member of the Ceramic Society, and were somewhat carpingly criticised by Mr. Bernard Moore, a representative of the manufacturers on the late Departmental Committee. How Mr. Thomason effectually disposed of Mr. Moore in the course of the subsequent discussion, will be evident to any unprejudiced reader.

It is not to be expected that in such a journal as we are noticing there would be much reading pour rive. But in the concluding paper, which tells of a visit paid by the society to a white-lead works, where the members seem to have been most hospitably entertained by the proprietors, there is a very distinct flavour of comedy. After the luncheon, one of the senior members of the party made an attempt to express the gratitude of the society to their quondam hosts. Unfortunately the speaker had evidently been much perturbed by the sight of a lavatory basin marked "leadless glaze," and this untoward circumstance, combined with the influence of "a sumptuous table" from which the party "had almost succeeded in abolishing that 'dangerous element,' water," led him to make an ill-mannered and vituperative attack upon what he was pleased to call "a band of faddists who had little better with which to occupy their meddlesome minds" than to bring down upon the trade "a perfect plague of inspections, committees, arbitrations, and commissions." But the orator took heart of grace. He did not despair "so long as they had such friends as $M r$. Bernard Shaw on the Lead Commission." Mr. Shaw is as ubiquitous as King Charles's head, but it is a little hard on him to confound him with Mr. Bernard Moore, with whom he has little in common. The sorry thing is that the silly speech reflects the attitude of a not inconsiderable section of the manufacturers to what is a great and crying evil in their industry.

\section{AN INSTITUTE OF HUMAN PALAEONTOLOGY.}

THE Prince of Monaco, as is well known, is a scientific man of high attainments, more especially in the sphere of oceanography. His own researches and those conducted under his auspices have been of first importance. A short time ago an account was given in these columns of the beautiful and well-equipped Museum of Oceanography which he erected at Monaco, and in last week's NATURE (p. 379) mention was made of the Oceanographical Institute founded and endowed in Paris by the Prince. As stated in another column, the institute was inaugurated on Monday, January 23, and it is hoped to give an account next week of the opening.

In I872 M. Émile Rivière discovered the first Palæolithic skeletons of the Baoussé-Roussé caves ("The Red Caves ") or Grimaldi caves, as it was decided they should be called at the International Congress of Anthropology and Prehistoric Archæology at Monaco in 1906. Later investigations revealed fresh remains, and the Prince himself in Igot discovered the fourth grave, that of the two famous "Negroids." The Prince took great interest in these important discoveries, and generously assisted in the work which was mainly conducted by the Canon de Villeneuve, Profs. Boule, Verneau, and Cartailhac. A great deal has been written on these finds in various journals, and the official reports have been published by the Prince in two volumes; he has also established a Museum of Archæology at Monaco. The Prince was so much impressed by the wonderful mural engravings and frescoes of Palæolithic age which adorn so many caves in central and south France and north Italy that he commissioned Dr. Émile Cartailhac and l'Abbé $\mathrm{H}$. Breuil to make a thorough investigation of

$$
\text { No. } 2 \text { I } 52 \text {, VOL. } 85]
$$

them, which, with his customary munificence, will be published in a series of sumptuous monographs, of which the first "La Caverne d'Altamira à Santillanc pres Santander (Espagne)," has recently appeared. In the current number of l'Anthropologie (tome xxi., p. 725), it is stated that the Prince has decided to found in Paris an institute of human palæontology. In a letter to the Minister of Instruction announcing his decision he says that he has come to feel that greater prominence should be given to the study of the mystery which shrouds the origin of mankind, and that a methodical basis of archæological investigation is required. "Et je pensais que la philosophie et la morale des sociétés humaines seraient mơins incertaines devant l'histoire des générations, écrite avec leur propre poussière." Having seen that oceanography was fittingly domiciled in Paris and Monaco, he gave some attention to the requirements of human palæontology.

The Prince goes on to state his intention of founding in Paris a centre for the pursuit of studies based on systematic excavation. The site for the institution has been selected, and the staff and a financial board of management appointed. The munificent founder adds that he has endowed the "Institut de Paleontologie humaine" with the sum of $1,600,000$ francs, and proposes to make over his collections to it conditionally. The Prince, desirous of securing the most favourable terms of existence for this foundation, begs the Government to recognise its value and approve its statutes.

A. C. H.

\section{NOTES.}

THE death of Sir Francis Galton at Grayshott House, near Haslemere, on January 17 , marks another link broken with the greater leaders of nineteenth-century science. Sir Francis passed away quietly after only a few days' illness, clear in mind, and able within a few hours of his death to question his physician humorously as to the statistics available for the reputed action of strychnine as a drug. By his own desire his body was interred at Clavendon, near Warwick, a peaceful country churchyard, close to the house which had once been the home of his mother (Violetta Darwin), and still remains a spot with much of artistic interest to those who value the family history of a noteworthy scientific stock. The funeral took place an Saturday, January 2r, the Master of Trinity College (representing the University of Cambridge and the college) and the vicar of Clavendon taking the service. Among the relatives and friends present were Miss E. Biggs, Mr. and Mrs. E. G. Wheler, Father Charles Galton, S.J., Major Hubert Galton, Miss Violet Galton, Mrs. Moilliet, Major Guy Lethbridge, Mr. Geoffrey Butler, Mr. A. F. G. Butler, Charles Galton Darwin, Miss A. Jones, and Prof. K. Pearson. The Royal Society was represented by Sir George Darwin and Mr. William Bateson, the former also representing the Royal Meteorological Society; Prof. A. Dendy represented the University of London and King's College; Major Leonard Darwin, the Royal Geographical Society; Dr. Charles Chree, the Kew Observatory; and Dr. David Heron, the Galton Eugenics Laboratory. We hope next week to publish some account of Sir Francis Galton's life and work.

THE two principal candidates for the vacant seat in the Paris Academy of Sciences caused by the death of $M$. Gernez were Mme. Curie and Prof. E. Branly. At the meeting of the academy on Monday, January 23, Prof. Branly was elected to the vacancy by the narrow majority of two votes. In the first ballot he received 29 votes against 28 given to Mme. Curie, and in the second $3^{\circ}$ 